\title{
Social-ecological inventory in a postdisaster context: the 2016 Kaikōura earthquake, Aotearoa-New Zealand
}

\author{
Nicholas A. Cradock-Henry ${ }^{1}$, Franca Buelow ${ }^{1,2}$ and Joanna Fountain ${ }^{3}$
}

\begin{abstract}
Natural hazards continue to have adverse effects on communities and households worldwide, accelerating research on proactively identifying and enhancing characteristics associated with resilience. Although resilience is often characterized as a return to normal, recent studies of postdisaster recovery have highlighted the ways in which new opportunities can emerge following disruption, challenging the status quo. Conversely, recovery and reconstruction may serve to reinforce preexisting social, institutional, and development pathways. Our understanding of these dynamics is limited however by the small number of practice examples, particularly for rural communities in developed nations. This study uses a social-ecological inventory to document the drivers, pathways, and mechanisms of resilience following a large-magnitude earthquake in Kaikōura, a coastal community in Aotearoa New Zealand. As part of the planning and implementation phase of a multiyear project, we used the tool as the basis for indepth and contextually sensitive analysis of rural resilience. Moreover, the deliberate application of social-ecological inventory was the first step in the research team reengaging with the community following the event. The inventory process provided an opportunity for research partners to share their stories and experiences and develop a shared understanding of changes that had taken place in the community. Results provide empirical insight into reactions to disruptive change associated with disasters. The inventory also informed the design of targeted research collaborations, established a platform for longer-term community engagement, and provides a baseline for assessing longitudinal changes in key resilience-related characteristics and community capacities. Findings suggest the utility of social-ecological inventory goes beyond natural resource management, and that it may be appropriate in a range of contexts where institutional, social, and economic restructuring have developed out of necessity in response to felt or anticipated external stressors.
\end{abstract}

Key Words: best practice, disaster, disaster, earthquake, natural hazards, rural resilience, stakeholder engagement

\section{INTRODUCTION}

Loss and damages from disaster continue to escalate globally, with implications for human well-being, economic development, and sustainability (Gall et al. 2011, Cutter et al. 2015). Driven in part by the rise in weather-related damages, the trend in rising losses is occurring against the backdrop of continued population growth, rising inequality, and political and economic instability (Mechler and Bouwer 2015). There is a growing consensus among researchers, policy makers, and practitioners that fundamental changes toward greater resilience are urgently required (Kates et al. 2012, Walker and Salt 201). This is reflected in the evolution of applied risk research over the previous decades (Miller et al. 2010, Hufschmidt 2011). Research has shifted from an emphasis on risk reduction to reducing vulnerability and to building resilience (Cutter et al. 2008, Fekete and Hufschmidt 2014, Tanner et al. 2015). Whereas early conceptualizations of resilience emphasized the capacity of impacted systems to bounce back, more recent research is drawing attention to the influence of nonlinear change, interrelationships, and dynamism across scales. Attention is being given not only to the resilience "of what, to what," but crucially, resilience of what type and for whom (Tanner et al. 2015) and to what end (Cloke and Conradson 2018, Dickinson 2018). Critical scholarship is focusing more closely on the socially constructed nature of resilience, the factors that shape it, and the dynamic interactions that mediate humanenvironment relationships (Cretney 2014). This scholarship pays particular attention to the ways in which dominant discourses might be challenged following a disaster and the emergence of new power relations (Hayward 2013, Cretney 2018).
Enhancing resilience to disasters is particularly relevant for Aotearoa New Zealand ("New Zealand"). New Zealand is a small, developed, export-led country, located on and adjacent to several active plate boundaries (Lamb 2015). This combination of high levels of seismicity, its location in the Pacific, local relief, and varied topography result in a dynamic and complex hazardscape (Khan 2012, Spector et al. 2018). In September 2010, the first major earthquake in 80 years in an urban area struck Christchurch, the largest city on the South Island. This was followed 6 months later by a second, more damaging event in terms of property damage and loss of life. In 2013, earthquakes affected the productive agricultural regions of MarlboroughBlenheim (Holden et al. 2015), and then in late 2016, the most recent quake occurred, its epicenter near the small rural community of Kaikôura on the South Island (Stevenson et al. 2017, Cradock-Henry et al. 2018) (Fig. 1).

As a percentage of gross domestic product (GDP), New Zealand's economic losses due to natural hazards are the highest in the Organisation for Economic Co-operation and Development (OECD), due in part to significant exposure of its primary industries, which contribute $7 \%$ of GDP and account for $79 \%$ of export earnings (OECD 2017, Statistics NZ 2018). Earthquakes (Whitman et al. 2013, Cradock-Henry and Fountain 2019), floods (Smith et al. 2011), drought (Harrington et al. 2014, Salinger et al. 2019), and wildfire (Langer and McGee 2017) are not uncommon, with adverse effects for the country's trade-oriented economy (Stroombergen et al. 2006).

${ }^{1}$ Landscape Policy \& Governance, Manaaki Whenua - Landcare Research, ${ }^{2}$ Department of Political Science, University of Kiel, ${ }^{3}$ Faculty of Environment, Society and Design, Lincoln University 
Fig. 1. Map of New Zealand, location of 2016 Kaikōura earthquake epicenter and major urban centers.

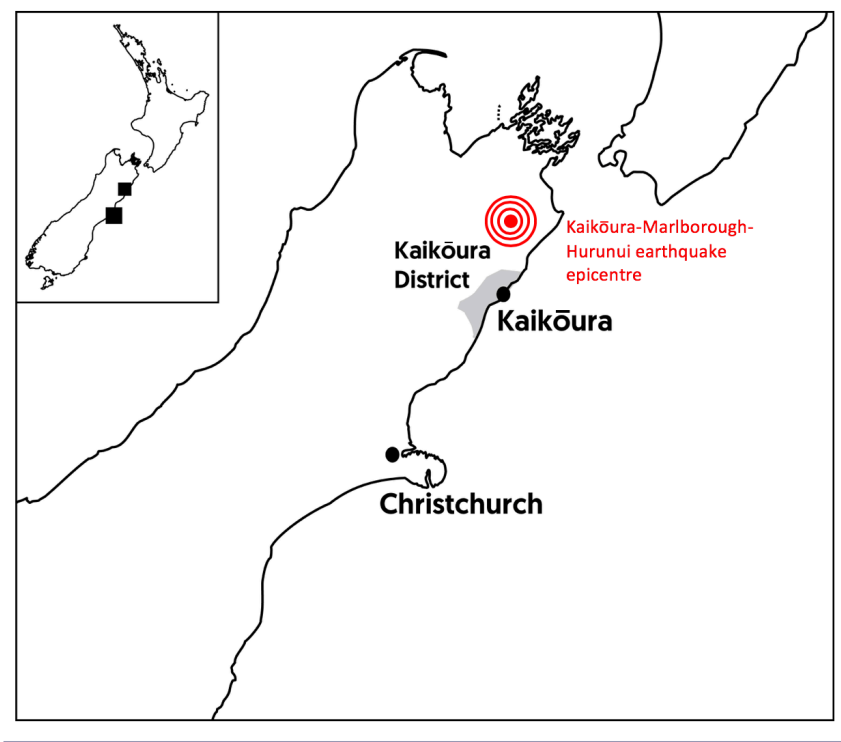

Rural regions in New Zealand and elsewhere continue to face particular challenges in relation to emergency management. In addition to being exposed to potential economic losses, they are also more exposed to geoclimatic hazards. Rural populations may be dispersed across less accessible landscapes and, as a result, may experience prolonged postevent isolation if infrastructure is damaged. Widespread structural changes in rural regionsdeclining service provision and an ageing population, for example - compound these challenges (Smith et al. 2011). At the same time, rural populations are often presumed to be more resilient than urban communities, despite current statistics that indicate higher levels of mental illness and suicide in rural areas (Alston 2012, Hutching 2017). Identifying and enhancing the characteristics of social-ecological systems (SES) that confer resilience is one way in which rural communities, industries, and organizations can successfully cope with, recover from, and manage change (Gunderson 2000, Walker et al. 2009).

The following study seeks to gain insight into the resilience-related dynamics of postevent recovery in a small rural community. More specifically, the study uses a social-ecological inventory (SEI) an approach originally developed for conservation and land-use planning (Schultz et al. 2007, 2011) - to better understand the complexity and linked nature of social and ecological systems as well as the importance of local knowledge in understanding these interactions (Folke et al. 2005, 2010, Schultz et al. 2007, Baird et al. 2014b). Social-ecological inventories provide a way to incorporate local-scale perspectives on an issue, recombining ordinary ecological inventories and stakeholder analysis (Baird et al. 2014b) consistent with "resilience thinking" (Walker and Salt 2012).

Although SEIs have been conducted elsewhere, their application has been limited to selected analytical foci and geographic contexts. Completed SEIs have focused either on natural resource and biodiversity management or climate change adaptation in Canada and Sweden (Schultz et al. 2007, Baird et al. 2014b, Plummer et al. 2016), with a single adaptation example from Bangladesh (Bahauddin et al. 2016). The technique is used in the following study to identify the ways in which the community is enhancing their resilience through the protection and restoration of valued resources, the emergence of new practices, and emerging collaborations and networks in a postdisaster context. The goal has been to establish a basis for ongoing research in the community through a sensitive and considered approach to determining stakeholders' research needs and priorities.

The paper is organized as follows: a discussion of resilience and its relationship to research design is next, in which we draw on the concept of adaptive cycles to consider resilience-related dynamics following a disaster. We then introduce the study context, the application of the SEI technique, and data analysis. Results of the inventory are discussed next. The paper ends with comments regarding the performance and potential for the application of this inventory technique elsewhere.

\section{RESILIENCE AND RESEARCH DESIGN}

Resilience concepts have gained significant ground in sustainability science (Derissen et al. 2011, Cutter 2014, Folke et al. 2016), disaster risk reduction (Adger et al. 2005, Alexander 2013), natural resource management (Walker et al. 2009, Wang and Blackmore 2009, Folke et al. 2010), and climate change adaptation (Funfgeld and Mcevoy 2012, Davoudi et al. 2013, Deppisch and Hasibovic 2013) as part of broader trends relating to disciplinary convergence and threats to human security and well-being. In the broadest sense, resilience describes the capacity of people, places, institutions, and activities to cope with change and respond to adversity (Adger 2000, Berkes and Ross 2013). The concept of resilience is useful for guiding and supporting more inclusive and effective approaches to the management of ecosystems and dependent societies. In particular, it offers a systematic framework for understanding how best to mitigate the effects of adverse events and support adaptation (Cannon and Müller-Mahn 2010, Tanner et al. 2015). It is valued as a framework for studying the management of SES dynamics, considering social and ecological (social-ecological) systems as intrinsically coupled and facing constant change, the outcomes of which are inherently unpredictable (Walker et al. 2004: 20, Anderies et al. 2006, Duit et al. 2010).

Resilience originated in ecology, where it is conceptualized as: (a) the amount of disturbance that an ecosystem can withstand without changing self-organized processes and structures; and (b) the return time to a (new) stable state following a perturbation (Morecroft et al. 2012). Literature combining social and ecological systems thinking defines "resilience" as "the capacity of a system to absorb disturbance and reorganize while undergoing change so as to still retain essentially the same function, structure, identity, and feedbacks" (Walker et al. 2004). In this context, resilience can be described by four defining characteristics (Walker et al. 2006):

1. The amount of change the system can undergo and still retain the same functions and structure - in other words, its ability to remain within the same stability domain or "regime"; 
2. The degree to which the system is capable of selforganization;

3. The ability to build and increase the capacity for learning and adaptation;

4. The capacity to transform part or all of the system into a different kind of system when the existing one is in an irreversibly undesirable state, or on a trajectory toward such a state.

These four characteristics of resilience can be viewed as part of an "adaptive cycle" (Walker et al. 2006, Brand and Jax 2007, Daedlow et al. 2011, Berkes and Ross 2013). A system's adaptive capacity is reflected by its coping range, which is location specific, group specific, and time specific (Smit and Pilifosova 2003). Working to improve specific coping capabilities by enhancing one or more of its underlying determinants is said to build adaptive capacity for reducing vulnerability to a specific stress (Yohe and Tol 2002). However, the determinants of adaptive capacity vary considerably by region, sector, and system (Yohe and Tol 2002, Engle 2011). There is no "one size fits all" capacity to adapt, making it all the more important to identify specific drivers that apply in those specific systems, sectors, and regions in a transparent research process, which can help facilitate comparison across contexts (Gupta et al. 2010, Hinkel 2011, Cinner et al. 2018).

Resilience can be applied precisely_for example, as a quantitative measure of subjective stress - or used in an exploratory capacity to gain insight into the emergent properties of dynamic systems (Hutching 2017). For the most part, it is used abstractly with only a limited number of examples of operationalization for practical purposes, particularly for mixed human-natural systems (Turner 2010). Several models have been proposed for empirically assessing resilience (Cutter et al. 2008, Walker et al. 2009, Becken 2013). For example, Walker et al.'s (2009) stability landscape model may be used to describe the state space - a snapshot - of an SES and its variables at any given time. A system is considered resilient if it maintains its configuration when exposed to stress or a shock (Walker et al. 2004, Anderies and Janssen 2011) This stable state, or domain (Gunderson 2000), can be characterized by three properties: resistance, latitude, and precariousness, corresponding to impacts, flexibility, or adaptability, and thresholds or tipping points. Qualitative assessments using this model have been developed for tourism in relation to climate change (Becken 2013) and for earthquake resilience in the wine industry (Cradock-Henry and Fountain 2019). In both instances, the application of the model relied on open-ended questioning regarding the drivers of change, the capacity for response, and the perceived presence or absence of critical thresholds as opposed to seeking to derive quantitative measures.

Cutter et al.'s (2008) Disaster Resilience of Place (DROP) model, on the other hand, focuses on the development of quantifiable comparative assessment of community resilience. The model proposes a set of variables representative of a linked humannatural system (e.g., area of wetlands to mitigate flood risk; demographic characteristics; local understanding of risk), which might be linked to indicators to derive metrics for assessing and comparing resilience across different settings (Cutter et al. 2008).
Our aim in applying SEI was to gain insight into the specific needs and contexts of a rural community dealing with a large-magnitude earthquake. Rather than seeking to determine a quantifiable measure of resilience, our focus was on the interaction between the natural environment and the ways in which human activity values, uses, and responds to naturally occurring variability and change (Walker et al. 2009). As such, we view resilience in terms of the capacity of an SES to respond to and recover from disaster. This includes the pre-event characteristics and capacities of the community, in this instance, to absorb impacts and cope with an event, as well as postevent, adaptive processes that facilitate the ability of the social system to reorganize, change, and learn in response to a threat, consistent with its application elsewhere (Adger et al. 2005, Cutter et al. 2008, Pahl-Wostl 2009, Miller et al. 2010).

By its design, SEI accounts for the dynamics - and the underlying or foundational constants - of an SES. It does so by documenting the patterns of organization within a community, including individual perceptions, values, relationships, and physical and social structures, as well as memories (van Aalst et al. 2008). In the context of the Kaikôura region, gaining insight into the factors and conditions that endured through the earthquake and subsequent disruption; which changed; and which emerged as direct or indirect responses to events can provide new insight into the region's adaptive capacity. The application of SEI provides an opportunity to understand and learn from transformational change by exploring attitudes and values of diverse communities and individuals who have learned to live in an uncertain environment that constantly forces them to adapt and change.

\section{STUDY AREA AND METHODS}

The following study began as part of a larger program on rural resilience through the Rural Co-Creation Laboratory (RNC Rural 2015, 2018): Resilience to Nature's Challenges-Kia manawaroa - Ngā Akina o Te Ao Türoa, a decade-long investment to deliver fundamental and applied risk and resilience science for New Zealand (Thompson et al. 2017). In mid 2016, the team identified Kaikôura and surrounding area as a case study site and began to engage with local stakeholders. Located on the east coast of the South Island, the town has a usually resident population of just 2,000 persons, with an additional 1,500 in the surrounding district (Statistics NZ 2014). As a small, peripheral region, dependent on primary and tertiary economic activities, Kaikôura is broadly representative of the social, environmental, cultural, and economic challenges facing rural regions. Furthermore, it is situated within a dynamic, multihazard landscape, exposed to earthquake, wildfire, tsunami, and landslide risks. Kaikôura District is New Zealand's smallest by area and has the lowest rating base in the country, limiting the amount of revenue raised from property valuation.

Kaikôra and the adjacent peninsula have been settled nearly 1000 years by indigenous Mâori who travelled first from Eastern Polynesia, later merging with migrating iwi who moved south from the North Island in the late 16th century (Tau et al. 1992). Mâori make up nearly $20 \%$ of the local population (Statistics NZ 2014), and community life for Kaikôura Mâori (iwi) is centered on the Takahanga marae (meeting place). Previously established relationships with local civil defence and emergency managers, 
Fig. 2. A multicriteria comparison between potential study sites identified in Kaikoura prior to the 14 November 2016 earthquake. A traffic-light system was used to assess each criterion.

\begin{tabular}{|c|c|c|c|c|c|c|}
\hline Selection Criteria & $\begin{array}{l}\text { Queenstown- } \\
\text { Lakes }\end{array}$ & Kaikoura & Marlborough & Selwyn & Hurunui & West Coast \\
\hline \multicolumn{7}{|l|}{$\begin{array}{l}\text { Complex } \\
\text { hazardscapes }\end{array}$} \\
\hline \multicolumn{7}{|l|}{$\begin{array}{l}\text { Access to stakeholders } \\
\text { Ability to inform policy }\end{array}$} \\
\hline \multicolumn{7}{|l|}{$\begin{array}{l}\text { Current state of research } \\
\text { knowledge }\end{array}$} \\
\hline \multicolumn{7}{|l|}{$\begin{array}{l}\text { Inclusive of sectors } \\
\text { (agribusiness, tourism) }\end{array}$} \\
\hline \multicolumn{7}{|l|}{$\begin{array}{l}\text { Match to team skills, } \\
\text { logistics/accessibility }\end{array}$} \\
\hline $\begin{array}{l}\text { Vision Matauranga and } \\
\text { iwi considerations }\end{array}$ & & & & & & \\
\hline
\end{tabular}

tourism stakeholders, iwi, and local government; an absence of previous research; and more practical considerations such as proximity to the majority of the research team - a 3-hour drive away-were also factors in its selection (Fig. 2).

Bounded by an inland range to the west and the Pacific Ocean on the east, Kaikôura's economy is based on tourism. Approximately 200,000 visitors annually are drawn to the region primarily by opportunities for outdoor recreation and marine wildlife viewing. The community also benefits from its convenient location halfway between Christchurch and Picton where ferries depart for the North Island. Tourism is a significant economic driver $(22.8 \%$ of employment), and primary industries, including agriculture, forestry, and fishing, remain important (14.1\% of employment) (Infometrics 2018).

On 14 November 2016 at 00:02 NZST (UTC: 11:02 a.m., 13 November 2016), a magnitude (Mw) 7.8 earthquake struck the region. The Kaikôura-Marlborough-Hurunui earthquake (named for the most severely affected regions) involved 21 faults rupturing over an area of $200 \mathrm{~km}^{2}$. Road and rail connectionsincluding some 60 tunnels and 20 bridges - were severely damaged by surface faulting and thousands of coseismic landslides and would remain partially closed for almost a year, with implications for the region's farming, fishing, and tourism industries (Stevenson et al. 2017, Cradock-Henry et al. 2018, Fountain and Cradock-Henry 2019). In addition to road and rail networks, distributed infrastructure - water and power-were affected, and there was extensive property damage both in the town of Kaikôura and surrounding regions. In places, the physical environment was dramatically changed due to coastal uplift, landslips, and localized flooding. Six months on from the event, there was considerable uncertainty about the recovery process and the long-term implications for the community and its economy. Flow-on effects for tourism, productivity in the primary sector, and issues of social and psychological well-being were particularly pronounced, highlighting once again the vulnerability of New Zealand's rural communities to environmental risks and hazards (Dantas and Seville 2006, Smith et al. 2011, Thompson et al. 2017, Spector et al. 2018).
The current study sought to investigate resilience-related characteristics and capacities, practices, and collaborations in a postdisaster context. The focus was on developing an open-ended understanding of the diverse ways in which stakeholders are strengthening their resilience through new practices, networks and collaborations, and knowledge.

The choice of method was informed by the need to consider the close links between the natural environment, which provides the basis for much of the cultural and economic life of the community through marine tourism and fishing, and the social dynamics relating to a peripheral, rural community. Few tools are available that use this "integrated" approach; the majority focus either on the "social" system (identifying the stakeholders) or the "ecological" system. Preparing for, managing, and recovering from hazard events, however, involves elements of both human and natural systems. The process of developing the SEI followed the six steps outlined by Schultz et al. (2011) and is broadly consistent with its application elsewhere (Baird et al. 2014, Plummer et al. 2016, Bahauddin et al. 2016) (Fig. 3).

The SEI begins with a preparatory phase in which goals are defined, ground rules established, ethics protocols obtained, and survey instrument(s) developed (Schultz et al. 2011). This initial phase is also vital for identifying boundary organizations and establishing trust and researcher transparency in order to ensure legitimacy. Additional consideration was given to the timing of the fieldwork and, due to the long-term nature of the program (2015-2024), the need to engage with the community respectfully and sensitively, acknowledging the heightened ethical risk with working in disaster-affected communities. For our research, this preparatory phase was also an opportunity to clearly communicate expectations, highlight the inclusive nature of the project and our emphasis on cocreation (RNC Rural 2015).

In the second step, key informants are identified, and the extent of their networks, roles, and responsibilities determined. Data collection to gain insight into knowledge, activities, and networks relating to the issue(s) under investigation is undertaken in the third step, often through surveys or interviews. Following data collection, the SEI protocol recommends pausing and reflecting 
Fig. 3. Phases of social-ecological inventory (redrawn after Baird et al. 2014a)

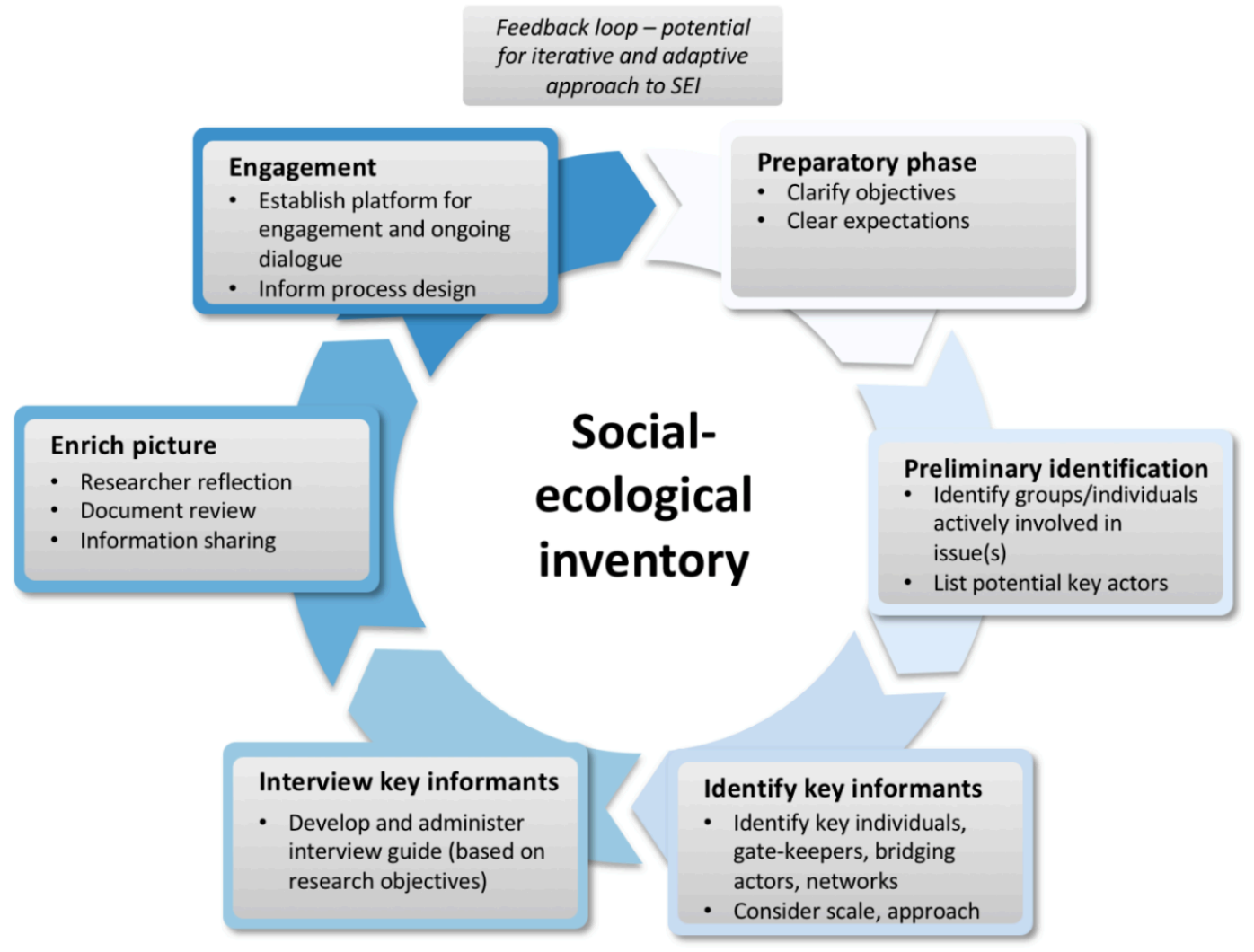

on initial findings. In the final stage, mechanisms or a platform for ongoing engagement and dialog are established to address common concerns. This process is seen as iterative (Schultz et al. 2007) and may be revisited over time.

Interview questions were developed in advance based on a close reading of the literature (Folke 2006, Pahl-Wostl 2006, Walker et al. 2006, Baird et al. 2014a). They were designed to solicit information on the components of resilience as they relate to the adaptive cycle: (1) perceptions of resilience, (2) activities and practices, and (3) collaborations and networks. Each interview used a consistent schedule of questions to ensure all issues were discussed with every informant.

Key informants were identified through existing research networks and relationships with individuals who had been involved in the initial scoping of the project. From this initial group of informants $(n=3)$, snowball techniques were used to identify additional interviewees $(n=9)$. The first round of interviews involved 12 individuals from 10 organizations. All those interviewed had direct experience with the earthquake and postevent recovery, and included personnel from local and regional government, civil defence, and emergency management, service providers, and local business operators who also had advisory or advocacy roles in the community. Data were supplemented by a further 15 interviews over the following 12 months. Interviews lasted approximately 45 minutes to 1 hour. Interviews were recorded and transcribed.
Interview data were analyzed using a deductive-inductive coding method to identify common themes related to the three components of resilience identified above. Coding was iterative and collaborative, with initial coding by the first and second authors, and results discussed with the third author as a means of validation. The characteristics of the adaptive cycle outlined in above were used to group responses with similar characteristics and comment on perceived drivers of change, including pathways and mechanisms of change.

\section{RESULTS}

Results from the SEI are presented below. The following subheadings correspond to each of the three main areas of investigation. In the first main area, informants were asked to describe whether or not Kaikôura was resilient, approximately 8 months postevent and, in some cases, up to 18 months later. The second main area sought to identify present activities - categories of resilience practice - relating to enhancing resilience in the community, and actors' rationale for these efforts. The third main area of inquiry investigated the emergence of new networks and collaborations, or changes to existing ones, that might help contribute to resilience. Results are conveyed in terms of major and minor themes arrived at through the coding process. Examples are presented throughout the results to convey the richness of the information gained. 


\section{Resilience dynamics and drivers}

In order to gain insight into local knowledge, beliefs, and values regarding the drivers and characteristics of resilience, as well as any perceived barriers, interviewees were asked to describe the resilience of Kaikôura and its drivers. Despite the significant challenges relating to isolation and accessibility, the impacts to built infrastructure, and economic effects, nearly all interviewees described the community as being very resilient, placing a strong normative emphasis on positive social characteristics. "From day one," said one interviewee, "this is not a community that sits down and feels sorry for itself. [Our] spirit is very resilient, and we're very willing to take ownership of problems and deal with it." "Yes, [Kaikôura] weathered some shocks but there is a lot of connectedness," said another. Most of the terms used to describe the community were positive and based on social cohesion and inclusiveness: "warm and inviting," "looking forward," "proactive," "people are connected."

In addition to the positive view of the community's overall state, these social characteristics were the most frequently cited factors in contributing to the resilience of the community. This was conveyed not only in terms of social cohesion and connectedness, but also optimism and a "can-do" attitude. There was also frequent mention of a willingness to collaborate and cooperate - between business operators, as well as the many community, faith, social, and cultural groups in the community. Many informants felt the community's relative isolation had fostered a deep sense of self-reliance; people were accustomed to the economic and seasonal cycles common to resource- and tourismdependent communities. Interviewees also described their connection and place attachment to Kaikôura and how that influenced their resilience individually and collectively.

In order to further understand the current state of resilience and help inform the design of targeted applied resilience research, interviewees were asked to reflect on the community's capacity to sustain and enhance its resilience postquake. As with responses to the previous line of questioning, respondents nearly all described the opportunities for development, learning, and transformation as a direct consequence of the earthquake. Respondents recognized that leveraging this "window of opportunity" (Brundiers and Eakin 2018) was vital; as one informant stated "No one wants an earthquake... but what's come out of that is going to be of great benefit to our community."

The most frequently cited benefits were social and economic opportunities. The earthquake raised the profile of the community in the minds of the general public and local and national government. It also highlighted the region's importance as a tourist destination, as well as a critical transportation link, and the loss of these roles generated sympathy. The economic opportunities were frequently referred to, especially with the rebuilding and restoration of critical infrastructure, which resulted in an additional 1,200 direct jobs for road and rail reconstruction alone. "The work that's out there is making a massive change in our resilience... there are young people who had no work at all who now have well paid work, above the living wage," said one interviewee. Improvements to State Highway 1which prior to the earthquake was subject to frequent closures during adverse weather events - were also viewed as enhancing the resilience of the community, with the potential to attract new businesses into the district. Small businesses also described changes in terms of opportunities for new learning or diversification. For example, one retailer had shifted to online sales in order to reach a larger market, whereas another marketed directly to the influx of rebuild workers. At a higher level, interviewees spoke proudly about the award-winning "Hospo Project," a collaboration between 22 local hospitality businesses and food outlets to cater lunch and dinner to hundreds of rebuild workers, enabling these businesses to remain commercially viable and retain staff (Fountain and Cradock-Henry 2019).

Tourism operators also took advantage of new opportunities, diversifying product offerings, such as new land-based tours to view damaged sites and geological features. Sector and community groups also described new funding opportunities as a result of the quake, which they had been able to successfully leverage into a wide range of activities.

Although interviewees frequently spoke in positive terms about resilience, when asked about the barriers to building resilience and to identify any critical vulnerabilities that may impede its development, three major themes were identified: spatial characteristics, overdependence on tourism, and fiscal constraints. The spatial characteristics of the community were expressed most strongly by informants from local government and business operators, and related to road access, transportation, and logistics. As noted earlier, due to its location on the main north - south South Island highway, which connects to the port at Picton, and by ferry to the North Island, Kaikôura is a critical node in the national transportation infrastructure network. Road closures, alternative routing, and delays had direct financial implications for businesses, particularly relating to goods distribution and a steep decline in visitor arrivals. The northern section of the main road link was closed for a year following the quake, with traffic diverted to secondary roads, increasing travel times; rail services resumed for freight 16 months postevent, and passenger services 25 months after the earthquake.

Road closures not only had economic impacts for the community, but interviewees representing community, health, and well-being interests described the social impacts of limited access well. As a small community, many of the recreational activities - such as local rugby league - are in neighboring districts, making it difficult to attend games and practices, especially for young players. Another interviewee remarked on the impacts on learning opportunities and the costs of bringing in tutors, for example, who needed to stay overnight in Kaikôura if they were coming from Christchurch or Blenheim.

An additional subtheme-identified more frequently by rural actors, emergency management, and interviewees representing community groups - focused on impediments to effective and efficient communication between community members, specifically relating to engagement with local and central government regarding local needs and recovery priorities. Interviewees described this communications capability and capacity in terms of telecommunications infrastructure (limited mobile reception and access to broadband internet) as well as the capacity constraints of a small community dealing with a major disaster. Developing high-speed internet in Kaikôura, several respondents noted, might also help attract new industries, talentbased and flexible economies, and workers. 
The second most reported vulnerability for the community was its lack of economic diversification and the district's increasing dependence on tourism. Following the earthquake, tourism expenditure in Kaikôura dropped dramatically. Guest arrivals declined $85 \%$ compared with the same November-December period in 2015, and domestic and tourism spending fell from a record high of NZ\$125 million in 2016 (year to September) to NZ\$63 million the following year (Destination Kaikôura 2017).

Respondents from across the pool of interviewees described the way the earthquake "opened our eyes... we can't be reliant on tourism." Although there is economic activity generated by the rural sector-primarily dairy farming and fishing - the difficulties in transporting agricultural products postquake, the closure of the fishery due to contamination concerns, and the closure of the local cheese factory in the months prior to the 2016 quake only exacerbated the issue for interviewees (CradockHenry et al. 2018)

The third most frequently reported impediment to enhancing resilience encompassed various elements relating to the fiscal constraints of a small rural community and the council's limited ability to raise revenue through rate increases. Kaikôura District has a resident population of 3,500; put another way, a $1 \%$ rate rise by the council generates only an additional NZ\$50,000. Postquake, Kaikôura District Council was already anticipating annual rate increases of $6 \%$ for each of the following 3 years to maintain existing infrastructure (Kaikoura District Council 2016). Furthermore, the capital costs to replace community infrastructure, some of which was underinsured due to age, would require additional borrowing and affect council's capacity to service the debt. As one interviewee said, "We're constrained by our debt because of our population size... we can't go to our ratepayers for $20 \%$ increases." Furthermore, there are high levels of socioeconomic deprivation in the district (Yong et al. 2017), compounding the effect of a rate increase. "People are struggling personally," continued the interviewee, "it feels very difficult and for some people will genuinely make their lives much more difficult, but it's a financial reality."

Although these three themes were most commonly identified by respondents, other barriers to resilience were described by two or more respondents. These included difficulties in attracting and retaining professionals, including lawyers and medical personnel; accommodation and housing shortages, staff shortages for small businesses; and the ability of council and emergency management staff to manage their own well-being while responding to the needs of the community. More generally, the need for greater understanding by central government and external agencies of the needs of a remote, rural community and greater sensitivity to context was noted.

\section{Resilience-related activities and efforts}

The second major component of the SEI was to document the practices and activities that contributed to building resilience in the community. Consistent with a social-ecological perspective on resilience, such activities are central to enhancing connectivity, building capability and capacity, connecting residents and community members with their local environment, and delivering opportunities and pathways for learning. Following the 20102011 earthquakes in Christchurch, for example, a number of community-led recovery initiatives were established with the aim of facilitating broader public participation in the recovery process (Vallance 2015, Cloke and Conradson 2018, Dickinson 2018) and providing affected residents a way to positively engage with damaged and transitional spaces in the city during reconstruction (Reynolds 2015, Vallance and Carlton 2015).

Interviewees were asked to identify resilience-related activities they were actively involved in, where they took place, the activities' intended and unanticipated outcomes and to whom the benefits accrued. Most of the activities and practices reported by interviewees as influencing their resilience were related to "connection": fostering and enhancing social networks and building relationships with one another. This was followed by education and learning, environmental sustainability, and economic development and diversification. Fewer than half of the respondents identified specific practices related to hazards and risk management or disaster preparedness. Responses were coded and organized into categories as shown in Table 1. The results have been categorized and are presented in descending order of the number of reported instances of the practice.

The largest category of activities and initiatives described by interviewees was focused on connecting with one another. The importance of social networks during and following a disaster has been extensively documented, often using social network analysis (SNA) to characterize the structure of pre- and postdisaster patterns (Vallance and Carlton 2015). Relationships play a vital role in rebuilding and typically are characterized by the strengthening of existing networks rather than the establishment of new ones (Doerfel et al. 2013).

In Kaikôura, these activities were focused not only on connections with friends and neighbors, but extended to the practices aimed specifically at welcoming new residents, many of whom had come to the community soon after the earthquake to assist with the rebuild. For a small community, the influx of over 1,700 rebuild workers necessitated greater coordination and collaboration between social welfare agencies, local government, and private businesses. These formal and informal activities ranged from community meals to Facebook groups and had in common a collective emphasis on well-being.

The promotion, creation, enhancement, and brokering of learning opportunities for the community were also frequently identified by a broad range of respondents, including community and service providers, local government representatives, and business operators. Enhancing environmental sustainability was most often identified as a resilience-building practice by local government, business sector representatives, and community service providers and NGOs; these were the same respondents who highlighted economic development and diversification activities.

\section{Actor networks and relationships related to resilience}

The third and final objective of the SEI was to identify collaborative relationships and networks among key actors and institutions. Evidence from the literature suggests that disasters can catalyze the development of new, flexible learning organizations, in which reformers extend social-ecological relationships (Goldstein 2008, Cretney and Bond 2014, Imperiale and Vanclay 2016), create spaces for innovation (Cloke and Conradson 2018), and challenge countervailing forces (Hayward 2013, Dickinson 2018). 
Table 1. Categories of resilience-related practice (Source: research findings)

\begin{tabular}{|c|c|c|}
\hline Category of practice & $\begin{array}{l}\text { Description (reported by interviewees in order of } \\
\text { frequency) }\end{array}$ & Example of practice \\
\hline $\begin{array}{l}\text { Community connectivity and } \\
\text { relationships }\end{array}$ & $\begin{array}{l}\text { Social activities aimed at fostering relationships and } \\
\text { enhancing community networks }\end{array}$ & $\begin{array}{l}\text { Faith/community groups free weekly meals; } \\
\text { community newsletter }\end{array}$ \\
\hline Education and learning & Creating, enhancing, and brokering learning & Computer courses; business literacy courses; \\
\hline Science and research; & opportunities & research collaboration and outreach with \\
\hline Public education; & & universities \\
\hline \multicolumn{3}{|l|}{$\begin{array}{l}\text { Business education and professional } \\
\text { development; }\end{array}$} \\
\hline \multicolumn{3}{|l|}{ Trades and skills ; } \\
\hline \multicolumn{3}{|l|}{ "Soft skills" } \\
\hline Sustainability practice and planning & $\begin{array}{l}\text { Activities and/or policy development based on general } \\
\text { principles of sustainability and environmental best } \\
\text { management practices }\end{array}$ & Earth Check Certification Program \\
\hline Economic development and & Activities to market and promote Kaikôura & Kaikôura Tourism Recovery Group; Christchurch \\
\hline diversification & $\begin{array}{l}\text { domestically and internationally; develop new tourism } \\
\text { products; develop and diversify local economy, attract } \\
\text { new businesses }\end{array}$ & International Airport \\
\hline Public health and well-being & $\begin{array}{l}\text { Planning and activities to foster and promote health } \\
\text { and well-being in the community, especially youth and } \\
\text { the elderly and vulnerable }\end{array}$ & Free yoga classes \\
\hline Professional and legal advice & $\begin{array}{l}\text { Activities and opportunities to receive professional and } \\
\text { legal advice }\end{array}$ & $\begin{array}{l}\text { Visiting legal professionals; sector workshops legal, } \\
\text { HR, and financial advice }\end{array}$ \\
\hline Infrastructure development & Rebuilding and restoring infrastructure & $\begin{array}{l}\text { North Canterbury Transportation Infrastructure } \\
\text { Repair (NCTIR) }\end{array}$ \\
\hline Iwi and cultural activities & Māori-led or supported organizations and activities & Whana Orau Navigators \\
\hline Rural support and planning & $\begin{array}{l}\text { Activities and practices focused on the needs and } \\
\text { priorities and rural households and primary industries }\end{array}$ & $\begin{array}{l}\text { Rural Support Trust; rural banking and service } \\
\text { providers; Ministry for Primary Industries }\end{array}$ \\
\hline Risk and emergency management & $\begin{array}{l}\text { Reduction, readiness, response and recovery-related } \\
\text { activities to improve disaster and emergency } \\
\text { management }\end{array}$ & Evacuation planning \\
\hline Funding agencies and activities & Sourcing external funding for activities, including & Lotto (NZ); Rata Foundation; Ministry for \\
\hline & $\begin{array}{l}\text { central government, lotteries and gaming, foundations, } \\
\text { and NGOs to facilitate community development }\end{array}$ & Business, Innovation and Employment \\
\hline Recreational development & $\begin{array}{l}\text { Restoring and enhancing recreational opportunities for } \\
\text { community }\end{array}$ & $\begin{array}{l}\text { Rebuilding the local swimming pool; new surf } \\
\text { break and lessons; lobbying Sport Tasman and } \\
\text { feasibility study for replacing swimming pool }\end{array}$ \\
\hline Local governance, policy, and planning & $\begin{array}{l}\text { Local political and institutional processes through } \\
\text { which decisions are taken and implemented }\end{array}$ & $\begin{array}{l}\text { Reviewing response; long-term plan; recovery needs } \\
\text { assessment }\end{array}$ \\
\hline $\begin{array}{l}\text { Adaptation to socioenvironmental } \\
\text { change }\end{array}$ & $\begin{array}{l}\text { Management practices and activities in response to } \\
\text { actual and/or anticipated physical, social, and economic } \\
\text { changes }\end{array}$ & $\begin{array}{l}\text { Te Korowai (collaborative decision-making body); } \\
\text { sector recovery and planning groups }\end{array}$ \\
\hline Energy efficiency & $\begin{array}{l}\text { Efforts to improve residential energy efficiency, energy } \\
\text { security, and energy justice and reduce carbon emissions }\end{array}$ & $\begin{array}{l}\text { Community Energy Action; Winter warming } \\
\text { program }\end{array}$ \\
\hline Water protection & $\begin{array}{l}\text { Protection of surface water and groundwater resources } \\
\text { and areas of recharge }\end{array}$ & $\begin{array}{l}\text { Love the Lyell (river restoration group); Kaikôura } \\
\text { Water Zone Committee }\end{array}$ \\
\hline Place making & $\begin{array}{l}\text { Activities relating to the planning, design, and } \\
\text { management of public spaces in order to enhance well- } \\
\text { being }\end{array}$ & Yarn bombing \\
\hline
\end{tabular}

Interviewees were asked to identify organizations outside their own with whom they collaborate on resilience-related issues. This question was deliberately open-ended, with additional prompts provided only when further clarification was required. The focus was on not only existing collaborations, i.e., ones that had been in place prior to the earthquake, but also emerging and new collaborations and partnerships that might have been established as part of the response and recovery process.

Respondents identified a wide-range of local, regional, and national collaborations focusing on resilience, environmental management, health and well-being, economic development, and risk and emergency management. The number of collaborations and partnerships corresponded closely to the results in the previous section: the most frequent number of collaborations and partnerships were to do with creating and enhancing learning opportunities, followed by sustainability practice and community networks. These partnerships were not limited to local collaborations, rather interviewees emphasized the degree to which partnerships extended far beyond the local vicinity. As one interviewee said, "relationships are everything at a time like this."

In the months after the earthquake, an array of new learning networks, relationships, and collaborations were advanced, 
enabling the community to self-organize and adapt by maintaining a heightened sensitivity to social and ecological interdependence brought on by the earthquake. Interviewees from across the community, including representatives from public health, local government, NGOs, business, environment, and iwi, identified a number of new learning- and education-focused collaborations as a direct result of the earthquake response and recovery. These ranged from formal agreements, for example with tertiary education providers, to more informal collaborations developed through personal relationships, but that resulted in learning opportunities for the community. The polytechnic in Christchurch established a 1-year business administration course for affected residents, and the university partnered with the local high school to develop opportunities for students to collaborate on research investigating the environmental impacts of the earthquake on aquatic systems. Drawing on extensive personal networks, one organization was able to successfully deliver a driver's education course for local youth-flying the instructor to town for several days a time; and local restauranteurs and hospitality workers received advice and were provided with professional development opportunities. "We've had so much training opportunity since this," said one interviewee. Collaborations focused on well-being were also widely reported.

Previous research has suggested that following a disaster, organizations' efforts are most focused on survival, drawing on established relationships and networks instead of expending energy on developing new ones (Doerfel et al. 2013). In Kaikôura, however, interviewees described a significant number of new partnerships and collaborations with national and Christchurchbased organizations, and emphasized the importance of these in enhancing their resilience. The Canterbury earthquake sequence (2010-2011) included two major earthquakes, resulting in 185 fatalities and NZ $\$ 40$ billion (US $\$ 28$ billion) in damages (Hayward 2013). As a result, a number of organizations in Christchurch were much more aware of the challenges facing Kaikôura, and immediately responded with a range of initiatives. In addition to the tertiary, public, and community education and learning opportunities discussed earlier; interviewees identified business support (including professional and legal advice, as well as capability and capacity development); and funding partnerships and agreements as the most common type of collaborations. Interviewees noted "fantastic training from the Canterbury Employers Chamber of Commerce," "the [Christchurch] Restaurant Association came up and offered assistance... whether you needed legal help, help managing staff, just real practical." Health care providers in particular described the way in which staff well-being was prioritized, and additional capacity provided for:

\begin{abstract}
The [District Heath Board] obviously had the experience of Christchurch so they were quick to be here in support in terms of psycho-social well-being as well as in terms of staffing. There were extra nurses brought up to staff the hospital... so that we could have staff go and have breaks which was really important to resilience. It enabled people to deal with their houses that were redand yellow-stickered... quite a lot of staff.
\end{abstract}

Although there were a number of new activities identified by interviewees, there were few new organizations. There were some exceptions, however; one was an infrastructure engineering consortium, tasked with the repair and rebuild (North Canterbury Transportation Infrastructure Repair (NCTIR)), and another was nine sectoral recovery groups (retail, hospitality, tourism, accommodation, construction and industry, primary industries and rural, essential services, professional services, sports and recreation) convened by council.

One organization has significantly enlarged its role in the community as a service provider, postquake; the Kaikôura Educational Trust had been inactive for several years prior to the event and had only recently been reincorporated as "Te Ha o Matauranga" ("Breath of Knowledge"). Following the earthquake, although its main function and identity had not changed, the group was able to dramatically scale up its activities to leverage funding opportunities for delivering learning opportunities for the community. Te Ha was also the organization with the greatest number of connections not only locally (with other providers), but regionally and nationally. The small group was responsible for acquiring significant funding from the Lotteries Corp. (NZ) and philanthropic trusts, and had established close working relationships with central government agencies such as the Ministry for Business Innovation and Employment (MBIE) and the NZ Transportation Authority. The group played an important role as a boundary or bridging organization within the community. Within the SEI, such organizations play a vital role in linking diverse interests, actors, and opportunities.

\section{DISCUSSION}

The particular needs of rural communities and the factors that contribute to resilience in areas characterized by remoteness, limited access, small populations, and/or challenging socioeconomic conditions have been broadly identified in the literature. Although examples of this work are only beginning to be undertaken in developed economies such as Aotearoa-New Zealand (Mitchell et al. 2010, Smith et al. 2011, Rouse et al. 2016, Cradock-Henry et al. 2018), results from the application of SEI in Kaikôura provide new insight into the dynamics of postdisaster recovery in a rural context. The phases of the inventory provide a practical framework for documenting and categorizing key facets of recovery, and the process of applying the tool helped establish pathways for further, ongoing engagement with the community and key actors, helped inform subsequent research activities, and as a consequence, has helped key researchers become a steady presence in the community.

Results provide conceptual insights into the dynamics of recovery and adaptive cycles. As one interviewee said, resilience is "an ongoing process of development, testing, learning — it's a bit like health and safety, it's managing the risks around what possibly could happen as practically as possible and then knowing how to respond to those things and it's an ongoing thing, I don't think you could ever say you've arrived with it." Resilience has - in some instances - been fairly criticized for a static view, which perceives it in terms of a preexisting structure that stretches and reacts to challenges (Brown and Westaway 2011, Olsson et al. 2015). However, results from our analysis of interview data suggest that most residents and other actors involved in the recovery regard resilience capability and capacity as something that is built around exposure to, or experience with, challenges. This "learn-as-you- 
go" attitude toward resilience is present throughout the interviews. This supports and provides additional empirical evidence for Pahl-Wostl's analysis of place-based learning and resilience (PahlWostl 2006, 2009). Although the direct and indirect impacts of the earthquake will continue to manifest for years to come, there is clear evidence of the formation of communities of practice in response to the disaster, which codify learning processes in "shared practices, tools, concepts, symbols, or material artefacts embedded in a context of meaning" (Pahl-Wostl 2006: 12). The district's annual plan, for example, a policy document required under the current national legislative framework, is framed around a very positive view of the earthquake, emphasizing throughout the opportunities for reimagining Kaikôura as part of the recovery process (Kaikoura District Council 2017).

Opportunities to develop location-specific, group-specific, and time-specific coping pathways and structures within a potentially vulnerable environment can also foster resilience that is founded on a localized experience and practice tradition (Smit and Pilifosova 2003, Folke 2006). The Kaikôura earthquake also comes as an opportunity, especially for businesses and local government. The momentous change that came with the disaster is interpreted as a chance to change institutionally, economically, and personally, as reactions to weaknesses and strengths that previous structures showed.

Studies of organizational resilience have suggested an absence of silos, flexibility, and relationships with stakeholders foster resilient structures (McManus et al. 2008). Our findings appear to support those conclusions, and the results of the analysis demonstrate how, particularly in rural regions, resilience capability and capacity build on existing administrative and taskbased redundancies as well as community ties at the local level. Some organizations were able to very quickly adapt their mandate (s) or activities to the changed context and situation; small businesses and council moved staff into new roles, and network configurations were changed to leverage goodwill and the visibility of the community into creating learning opportunities in particular.

Although some of our interviewees recognized the benefits of outside expertise, many interviewees reflected on their disappointment with higher administrative levels that did not understand the particular needs of the community. This illustrates not only the importance of deeper insight into the local context that shapes resilience - the main issues, drivers, and shocks (Walker et al. 2009) - but also the difficulties of national-level, centralized involvement in a disaster, and the need for developing appropriate relationships, pathways, and communications prior to an event. The need for expert advice and national guidance to help rural communities to prepare for and respond to disasters would ideally be balanced against the importance of local knowledge and practices (Jakes and Langer 2012, Rouse et al. 2016). Kaikôura residents' perceived lack of agency and empowerment potentially undermined their coping capacity.

Information sharing between organizations to improve warning systems and disaster management technologies can also enhance resilience and speed recovery (Dantas and Seville 2006, Leonard et al. 2008, 2014, Wilson et al. 2014, Huggins et al. 2015). The literature on resilience in New Zealand includes the significance of workshops and other forms of knowledge exchange to provide support services to community members before and after disasters
(Paton et al. 2001, Finnis et al. 2010, Britt et al. 2011, Orchiston et al. 2013, Cooper-Cabell 2016, Tipler et al. 2016, Cretney 2018). Workshops were shown to help individuals process hazards (Britt et al. 2011, Orchiston et al. 2013, Cooper-Cabell 2016), and participants become more resilient in terms of preparedness and hazards awareness (Finnis et al. 2010, Tipler et al. 2016). In the Kaikôura case, communication with Christchurch officials, staff exchange, and an increase in skilled volunteers with earthquake experience accelerated learnings on how to safeguard and integrate individuals, family and business units, iwi and hapu, communities, regions, and the urban and rural dynamics. The already lively community networks were a structure that both the rural population and external helpers could draw on in the aftermath of the earthquake.

In practical terms, empirically documenting the perceptions of community actors, the development of resilience-related activities and practices, and the emergence of new collaborative networks were also vital to the design of targeted research to meet the needs, priorities, and opportunities identified through the application of SEI. The inventory revealed the emergence of an SES perspective, linking marine- and land-based issues and concerns, and highlighted the ways in which social and economic issues in particular were prioritized. Furthermore, by beginning to understand community attitudes toward the recovery process as a normative, more positive and less negative experience, the team was also able to provide better support to stakeholders and leverage additional opportunities.

Research findings and results from the inventory have been used in a number of different ways. First, as noted above, the results have helped to inform the design of a number of targeted research projects. This includes work on the transformations for rural resilience (Cradock-Henry et al. 2018), land-use planning and community agency postdisaster (Rennie 2018), and regional food security (Fountain et al. 2019). A doctoral student is exploring community-led initiatives and their significance in fostering and maintaining community resilience by focusing on three of the categories of resilience-related practice identified (community connectivity and relationships, education and learning, and water protection) and specific case examples of activities in each of the categories (RNC Rural 2018).

Second, the process of conducting the inventory provided a pathway to reestablish trust with the community and key actors. Following the Christchurch earthquake, there was justified criticism of the way in which some researchers had not respected the needs and perspectives of affected residents, of insensitivity to the social and cultural context, and of bypassing established relationships in pursuit of data (Beaven et al. 2015). Mindful of this, the application of the tool provided a neutral forum to listen to stakeholders' experiences. A number of interviewees expressed gratitude for the opportunity to share their stories with people from outside the community. For the researchers, the SEI was a means of collecting valuable data and of gaining insight into the community, however, it was also an opportunity to develop trusted relationships, and the application of the tool provided a way to give something back to the community: to listen to people's stories and to acknowledge and validate the efforts being made.

Finally the process of conducting the inventory has helped develop the research team's capability and capacity as a boundary organization. Boundary organizations refer to a specific way of 
organizing the interface between science and policy (Impedovo and Manuti 2016, Gustafsson and Lidskog 2018). To enhance the impact of science and to enable learning, boundary organizations are required to support and facilitate knowledge exchange among scientists, policy makers, practitioners, and end users (Benn et al. 2013, Cvitanovic et al. 2018). Such arrangements must satisfy the demands of both science (credibility) and policy (relevance) in order to be effective and deliver impact (legitimacy) (Beaven et al. 2017). The application of the SEI has helped to enhance the scientific credibility of the research by identifying key knowledge gaps. However, it has also provided a process for engaging with and involving policy makers and practitioners to understand their research needs and priorities and obtain legitimacy with the community through the development of trusting relationships (Cash et al. 2003) to deliver research of practical value. For example, the team has connected community stakeholders with other research-funding opportunities and aligned research to clearly identified stakeholder needs.

\section{CONCLUSION}

The changing relationship between science, policy, and practice is increasing demands on research to engage more productively with stakeholders and end users in order to enhance the value of publicly funded research. This can be particularly acute in postdisaster settings where communities, households, and organizations may have limited capacity for engagement, are dealing with more urgent issues, or where contextual information is not readily available. To gain insight into the dynamics of resilience - which is very often locally specific, context dependent, and characterized by the networks, collaborations, and activities of actors-robust tools are needed to help facilitate the process of engagement, establish trusting relationships, and identify opportunities to work alongside actors to address priorities and concerns.

This study applied SEI in a small rural community in AotearoaNew Zealand in the months following a large magnitude earthquake. The intent was to: reestablish research and stakeholder networks within the region and document the dynamic changes in resilience-related perceptions (including the drivers and barriers to resilience); gain insight into activities and practices in the community aimed at building resilience; and identify established and emerging collaborations and networks. The results of the inventory provide an empirical record of the ways in which the community was reimagining itself in positive ways, emphasizing social connectivity, well-being, and networks. New collaborations - particularly with other organizations who had experience with earthquake recovery - and the emergence of an SES perspective on land- and marine-management issues also provided a pathway for the development of targeted research activities to meet stakeholders' priorities and needs.

Results demonstrate the broad suitability of the tool, which previously had been limited to natural resource management, and its capacity to assist with the identification of corresponding system dynamics. Although further case examples are required, SEI shows significant potential as a "priming" tool (Baird et al. $2014 b$ ) in diverse settings - including postdisaster - for sensitive, considered, and thoughtful collaborations, and to contribute to more resilient futures for rural and other communities.
Responses to this article can be read online at: http://www.ecologyandsociety.org/issues/responses. php/11075

\section{Acknowledgments:}

This research was funded by the Resilience to Nature's Challenges National Science Challenge through the NZ Ministry of Business Innovation and Employment, as part of the Rural Co-Creation Laboratory. Thanks to other members of RNC Rural for assistance with initial interviews. We gratefully acknowledge the constructive comments of two anonymous reviewers.

\section{LITERATURE CITED}

Adger, W. N. 2000. Social and ecological resilience: are they related? Progress in Human Geography 24(3):347-364. https://doi. org/https://doi.org/10.1191/030913200701540465

Adger, W. N., T. P. Hughes, C. Folke, S. R. Carpenter, and J. Rockström. 2005. Social-ecological resilience to coastal disasters. Science 309(5737):1036-1039. https://doi.org/https://doi.org/10.1126/ science. 1112122

Alexander, D. E. 2013. Resilience and disaster risk reduction: an etymological journey. Natural Hazards and Earth System Science 13(11):2707-2716. https://doi.org/https://doi.org/10.5194/ nhess-13-2707-2013

Alston, M. 2012. Rural male suicide in Australia. Social Science and Medicine 74(4):515-522. https://doi.org/10.1016/j. socscimed.2010.04.036

Anderies, J. M., and M. A. Janssen. 2011. The fragility of robust social-ecological systems. Global Environmental Change 21 (4):1153-1156. https://doi.org/10.1016/j.gloenvcha.2011.07.004

Anderies, J. M., P. Ryan, and B. H. Walker. 2006. Loss of resilience, crisis, and institutional change: lessons from an intensive agricultural system in southeastern Australia. Ecosystems 9(6):865-878. https://doi.org/10.1007/s10021-006-0017-1

Bahauddin, K. M., N. Rahman, and M. T. Hasnine. 2016. Public perception, knowledge, and participation in climate change adaptation governance in the coastal region of Bangladesh using the social ecological inventory (SEI) tool. Environmental Practice 18(1):32-43. https://doi.org/https://doi.org/10.1017/s1466046615000393

Baird, J., R. Plummer, C. Haug, and D. Huitema. 2014a. Learning effects of interactive decision-making processes for climate change adaptation. Global Environmental Change 27:51-63.

Baird, J., R. Plummer, and K. Pickering. 2014b. Priming the governance system for climate change adaptation: the application of a social-ecological inventory to engage actors in Niagara, Canada. Ecology and Society 19(1):3.. https://doi.org/http://dx. doi.org/10.5751/ES-06152-190103

Beaven, S., T. Wilson, L. Johnston, D. Johnston, and R. Smith. 2015. Research engagement after disasters: research coordination before, during, and after the 2011-2012 Canterbury earthquake sequence, New Zealand. Earthquake Spectra 32(2):713-735. https://doi.org/https://doi.org/10.1193/082714eqs134m 
Beaven, S., T. Wilson, L. Johnston, D. Johnston, and R. Smith. 2017. Role of boundary organization after a disaster: New Zealand's natural hazards research platform and the 2010-2011 Canterbury earthquake sequence. Natural Hazards Review 18 (2):05016003. https://doi.org/https://doi.org/10.1061/(asce) nh.1527-6996.0000202

Becken, S. 2013. Developing a framework for assessing resilience of tourism sub-systems to climatic factors. Annals of Tourism Research 43:506-528. https://doi.org/10.1016/j.annals.2013.06.002

Benn, S., M. Edwards, and T. Angus-Leppan. 2013. Organizational learning and the sustainability community of practice the role of boundary objects. Organization and Environment 26(2):184-202. https://doi.org/https://doi. org/10.1177/1086026613489559

Berkes, F., and H. Ross. 2013. Community resilience: toward an integrated approach. Society and Natural Resources 26(1):5-20. https://doi.org/10.1080/08941920.2012.736605

Brand, F., and K. Jax. 2007. Focusing the meaning(s) of resilience: resilience as a descriptive concept and a boundary object. Ecology and Society 12(1): 23 .

Britt, E., M. Dorahy, J. Carter, P. Hoggath, A. Coates, M. Meyer, and K. Naswall. 2011. Promoting recovery and building resilience for individuals and communities. New Zealand Journal of Psychology 40(4):76-78.

Brown, K., and E. Westaway. 2011. Agency, capacity, and resilience to environmental change: lessons from human development, well-being, and disasters. Annual Review of Environment and Resources 36(1):321-342. https://doi.org/10.1146/ annurev-environ-052610-092905

Brundiers, K., and H. C. Eakin. 2018. Leveraging post-disaster windows of opportunities for change towards sustainability: a framework. Sustainability 10(5):1390. https://doi.org/10.3390/ su10051390

Cannon, T., and D. Müller-Mahn. 2010. Vulnerability, resilience and development discourses in context of climate change. Natural Hazards 55(3):621-635. https://doi.org/10.1007/s11069-010-9499-4

Cash, D. W., W. C. Clark, F. Alcock, N. M. Dickson, N. Eckley, D. H. Guston, J. Jäger, and R. B. Mitchell. 2003. Knowledge systems for sustainable development. Proceedings of the National Academy of Sciences 100(14):8086-8091. https://doi.org/10.1073/ pnas. 1231332100

Cinner, J. E., W. N. Adger, E. H. Allison, M. L. Barnes, K. Brown, P. J. Cohen, S. Gelcich, C. C. Hicks, T. P. Hughes, J. Lau, N. A. Marshall, and T. H. Morrison. 2018. Building adaptive capacity to climate change in tropical coastal communities. Nature Climate Change 8:117-123.

Cloke, P., and D. Conradson. 2018. Transitional organisations, affective atmospheres and new forms of being-in-common: postdisaster recovery in Christchurch, New Zealand. Transactions of the Institute of British Geographers 43(3):360-376. https://doi. org/10.1111/tran.12240

Cooper-Cabell, N. 2016. Mind the gap: post earthquake community wellbeing? Aotearoa New Zealand Social Work 25 (2):27-34. https://doi.org/https://doi.org/10.11157/anzswj-vol25iss2id78
Cradock-Henry, N. A., and J. Fountain. 2019. Characterising resilience in the wine industry: insights and evidence from Marlborough, New Zealand. Environmental Science and Policy 94:182-190. https://doi.org/10.1016/j.envsci.2019.01.015

Cradock-Henry, N. A., J. Fountain, and F. Buelow. 2018. Transformations for resilient rural futures: the case of Kaikôura, Aotearoa-New Zealand. Sustainability 10(6): 1952. https://doi. org/10.3390/su10061952

Cretney, R. 2014. Resilience for whom? Emerging critical geographies of socio-ecological resilience: resilience of what, for whom? Geography Compass 8(9):627-640. https://doi.org/10.1111/ gec3.12154

Cretney, R. M. 2018. Beyond public meetings: diverse forms of community led recovery following disaster. International Journal of Disaster Risk Reduction 28:122-130. https://doi.org/10.1016/j. ijdrr.2018.02.035

Cretney, R., and S. Bond. 2014. "Bouncing back" to capitalism? Grass-roots autonomous activism in shaping discourses of resilience and transformation following disaster. Resilience 2 (1):18-31. https://doi.org/10.1080/21693293.2013.872449

Cutter, S. L. 2014. Building disaster resilience: steps toward sustainability. Challenges in Sustainability 1(2):72-79. https://doi. org/10.12924/cis2013.01020072

Cutter, S. L., L. Barnes, M. Berry, C. Burton, E. Evans, E. Tate, and J. Webb. 2008. A place-based model for understanding community resilience to natural disasters. Global Environmental Change 18(4):598-606. https://doi.org/10.1016/j.gloenvcha.2008.07.013

Cutter, S. L., A. Ismail-Zadeh, I. Alcántara-Ayala, O. Altan, D. N. Baker, S. Briceño, H. Gupta, A. Holloway, D. Johnston, G. A. McBean, Y. Ogawa, D. Paton, E. Porio, R. K. Silbereisen, K. Takeuchi, G. B. Valsecchi, C. Vogel, and G. Wu. 2015. Global risks: Pool knowledge to stem losses from disasters. Nature 522 (7556):277-279. https://doi.org/10.1038/522277a

Cvitanovic, C., M. F. Löf, A. V. Norström, and M. S. Reed. 2018. Building university-based boundary organisations that facilitate impacts on environmental policy and practice. PLOS ONE 13(9): e0203752. https://doi.org/10.1371/journal.pone.0203752

Daedlow, K., V. Beckmann, and R. Arlinghaus. 2011. Assessing an adaptive cycle in a social system under external pressure to change: the importance of intergroup relations in recreational fisheries governance. Ecology and Society 16(2): 3.

Dantas, A., and E. Seville. 2006. Organisational issues in implementing an information sharing framework: lessons from the Matata flooding events in New Zealand. Journal of Contingencies and Crisis Management 14(1):38-52. https://doi. org/10.1111/j.1468-5973.2006.00479.x

Davoudi, S., E. Brooks, and A. Mehmood. 2013. Evolutionary resilience and strategies for climate adaptation. Planning Practice and Research 28(3):307-322. https://doi.org/10.1080/02697459.2$\underline{013.787695}$

Deppisch, S., and S. Hasibovic. 2013. Social-ecological resilience thinking as a bridging concept in transdisciplinary research on climate-change adaptation. Natural Hazards 67(1):117-127. https://doi.org/10.1007/s11069-011-9821-9 
Derissen, S., M. F. Quaas, and S. Baumgärtner. 2011. The relationship between resilience and sustainability of ecologicaleconomic systems. Ecological Economics 70(6):1121-1128. https://doi.org/10.1016/j.ecolecon.2011.01.003

Destination Kaikôura. 2017. Kaikôura Earthquake Update No. 19, 14 November 2017.

Dickinson, S. 2018. Spaces of post-disaster experimentation: agile entrepreneurship and geological agency in emerging disaster countercartographies. Environment and Planning E: Nature and Space 1(4):621-640. https://doi.org/10.1177/2514848618812023

Doerfel, M. L., L. V. Chewning, and C.-H. Lai. 2013. The evolution of networks and the resilience of interorganizational relationships after disaster. Communication Monographs 80 (4):533-559. https://doi.org/10.1080/03637751.2013.828157

Duit, A., V. Galaz, K. Eckerberg, and J. Ebbesson. 2010. Governance, complexity, and resilience. Global Environmental Change 20(3):363-368. https://doi.org/10.1016/j.gloenvcha.2010.04.006

Engle, N. L. 2011. Adaptive capacity and its assessment. Global Environmental Change 21:647-656.

Fekete, A., and G. Hufschmidt. 2014. From application to evaluation: addressing the usefulness of resilience and vulnerability. International Journal of Disaster Risk Science 5 (1):1-2. https://doi.org/10.1007/s13753-014-0007-4

Finnis, K. K., D. M. Johnston, K. R. Ronan, and J. D. White. 2010. Hazard perceptions and preparedness of Taranaki youth. Disaster Prevention and Management: An International Journal 19(2):175-184. https://doi.org/10.1108/09653561011037986

Folke, C. 2006. Resilience: the emergence of a perspective for social-ecological systems analyses. Global Environmental Change 16(3):253-267. https://doi.org/10.1016/j.gloenvcha.2006.04.002

Folke, C., R. Biggs, A. Norström, B. Reyers, and J. Rockström. 2016. Social-ecological resilience and biosphere-based sustainability science. Ecology and Society 21(3): 41. https://doi.org/10.5751/ ES-08748-210341

Folke, C., S. R. Carpenter, B. Walker, M. Scheffer, T. Chapin, and J. Rockström. 2010. Resilience thinking: integrating resilience, adaptability, and transformability. Ecology and Society 15(4): 20. https://doi.org/10.5751/ES-03610-150420

Folke, C., T. Hahn, P. Olsson, and J. Norberg. 2005. Adaptive governance of social-ecological systems. Annual Review of Environment and Resources 30(1):441-473. https://doi.org/10.1146/ annurev.energy.30.050504.144511

Fountain, J., and N. Cradock-Henry. 2019. The road to recovery: reimagining Kaikoura after a natural disaster. Pages 33-58 in G. Walters and J. Mair, editors. Reputation and image recovery for the tourism industry. Goodfellow Publishers, Oxford, UK. https:// doi.org/10.23912/9781911396673-4123

Funfgeld, H., and D. Mcevoy. 2012. Resilience as a useful concept for climate change adaptation? Planning Theory and Practice 13 (2):324-328

Gall, M., K. A. Borden, C. T. Emrich, and S. L. Cutter. 2011. The unsustainable trend of natural hazard losses in the United States. Sustainability 3(11):2157-2181. https://doi.org/10.3390/su3112157
Goldstein, B. E. 2008. Skunkworks in the embers of the cedar fire: enhancing resilience in the aftermath of disaster. Human Ecology 36(1):15-28. https://doi.org/10.1007/s10745-007-9133-6

Gunderson, L. H. 2000. Ecological resilience - in theory and application. Annual Review of Ecology and Systematics 31(1):425439. https://doi.org/10.1146/annurev.ecolsys.31.1.425

Gupta, J., C. Termeer, J. Klostermann, S. Meijerink, M. van den Brink, P. Jong, S. Nooteboom, and E. Bergsma. 2010. The adaptive capacity wheel: a method to assess the inherent characteristics of institutions to enable the adaptive capacity of society. Environmental Science and Policy 13:459-471.

Gustafsson, K. M., and R. Lidskog. 2018. Boundary organizations and environmental governance: performance, institutional design, and conceptual development. Climate Risk Management 19:1-11. https://doi.org/10.1016/j.crm.2017.11.001

Harrington, L. J., S. Rosier, S. M. Dean, S. Stuart, and A. Scahill. 2014. The role of anthropogenic climate change in the 2013 drought over North Island, New Zealand. Explaining Extremes of 2013 from a Climate Perspective, Special Supplement of the Bulletin of the American Meteorological Society 95(9):S45-S48.

Hayward, B. M. 2013. Rethinking resilience: reflections on the earthquakes in Christchurch, New Zealand, 2010 and 2011. Ecology and Society 18(4): 37. https://doi.org/https://doi. org/10.5751/es-05947-180437

Hinkel, J. 2011. Indicators of vulnerability and adaptive capacity: towards a clarification of the science-policy interface. Global Environmental Change 21:198-208.

Holden, C., A. Kaiser, R. V. Dissen, and R. Jury. 2015. Sources, ground motion and structural response characteristics in Wellington of the 2013 Cook Strait earthquakes. Bulletin of the New Zealand Society for Earthquake Engineering 46(4):188-195.

Hufschmidt, G. 2011. A comparative analysis of several vulnerability concepts. Natural Hazards 58(2):621-643. https:// doi.org/10.1007/s11069-011-9823-7

Huggins, T. J., S. R. Hill, R. Peace, and D. M. Johnston. 2015. Assessing displays for supporting strategic emergency management. Disaster Prevention and Management: An International Journal 24(5):635-650. https://doi.org/10.1108/ DPM-05-2015-0100

Hutching, G. 2017. Farmer suicides highlight vulnerability as official figures rise for past year. Stuff: 19 December 2017. [online] URL: https://www.stuff.co.nz/business/farming/99964077/farmersuicides-highlight-vulnerability-as-official-figures-rise-for-past-year

Impedovo, M. A., and A. Manuti. 2016. Boundary objects as connectors between communities of practices in the organizational context. Development and Learning in Organizations: An International Journal 30(2):7-10. https://doi. org/10.1108/DLO-07-2015-0065

Imperiale, A. J., and F. Vanclay. 2016. Experiencing local community resilience in action: learning from post-disaster communities. Journal of Rural Studies 47:204-219. https://doi. org/10.1016/j.jrurstud.2016.08.002 
Infometrics. 2018. Kaikoura District Economic Profile. [online] URL: https://ecoprofile.infometrics.co.nz/Kaikoura\%2bDistrict/ Tourism/TourismEmployment

Jakes, P. J., and E. R. Langer. 2012. The adaptive capacity of New Zealand communities to wildfire. International Journal of Wildland Fire 21(6): 764. https://doi.org/10.1071/WF11086

Kaikoura District Council. 2016. Kaikoura District Council Annual Plan 2016-2017. Page 122. Kaikoura District Council, Kaikoura, NZ.

Kaikoura District Council. 2017. Reimagine Kaikoura - Pôhewatia anô a Kaikôura. Page 56. Kaikoura District Council, Kaikoura.

Kates, R. W., W. R. Travis, and T. J. Wilbanks. 2012. Transformational adaptation when incremental adaptations to climate change are insufficient. Proceedings of the National Academy of Sciences 109(19):7156-7161. https://doi.org/10.1073/ pnas. 1115521109

Khan, S. 2012. Disasters: contributions of hazardscape and gaps in response practices. Natural Hazards and Earth System Sciences 12(12):3775-3787. https://doi.org/10.5194/nhess-12-3775-2012

Lamb, S. 2015. Kinematics to dynamics in the New Zealand Plate boundary zone: implications for the strength of the lithosphere. Geophysical Journal International 201(2):552-573. https://doi. org/10.1093/gji/ggv027

Langer, E. R., and T. K. McGee. 2017. Wildfire risk awareness and prevention by predominantly Mâori rural residents, Karikari Peninsula, Aotearoa New Zealand. International Journal of Wildland Fire 26(9):820-828. https://doi.org/https://doi.org/10.1071/ $\underline{\text { wf16133 }}$

Leonard, G. S., D. M. Johnston, D. Paton, A. Christianson, J. Becker, and H. Keys. 2008. Developing effective warning systems: ongoing research at Ruapehu volcano, New Zealand. Journal of Volcanology and Geothermal Research 172(3):199-215. https:// doi.org/10.1016/j.jvolgeores.2007.12.008

Leonard, G. S., C. Stewart, T. M. Wilson, J. N. Procter, B. J. Scott, H. J. Keys, G. E. Jolly, J. B. Wardman, S. J. Cronin, and S. K. McBride. 2014. Integrating multidisciplinary science, modelling and impact data into evolving, syn-event volcanic hazard mapping and communication: a case study from the 2012 Tongariro eruption crisis, New Zealand. Journal of Volcanology and Geothermal Research 286:208-232. https://doi.org/10.1016/j. jvolgeores.2014.08.018

McManus, S., E. Seville, J. Vargo, and D. Brunsdon. 2008. Facilitated process for improving organizational resilience. Natural Hazards Review 9(2):81-90. https://doi.org/10.1061/(ASCE) 1527-6988(2008)9:2(81)

Mechler, R., and L. M. Bouwer. 2015. Understanding trends and projections of disaster losses and climate change: is vulnerability the missing link? Climatic Change 133(1):23-35. https://doi. org/10.1007/s10584-014-1141-0

Miller, F., H. Osbahr, E. Boyd, F. Thomalla, S. Bharwani, G. Ziervogel, B. Walker, J. Birkmann, S. van der Leeuw, J. Rockström, J. Hinkel, T. Downing, C. Folke, and D. Nelson. 2010. Resilience and vulnerability: complementary or conflicting concepts? Ecology and Society 15(3): 11. https://doi.org/https://doi. org/10.5751/es-03378-150311
Mitchell, A., B. C. Glavovic, B. Hutchinson, G. MacDonald, M. Roberts, and J. Goodland. 2010. Community-based civil defence emergency management planning. The Australasian Journal of Disaster and Trauma Studies 2010(1). [online] URL: http:// trauma.massey.ac.nz/issues/2010-1/mitchell.htm

Morecroft, M. D., H. Q. P. Crick, S. J. Duffield, and N. A. Macgregor. 2012. Resilience to climate change: translating principles into practice. Journal of Applied Ecology 49(3):547551. https://doi.org/10.1111/j.1365-2664.2012.02136.x

Olsson, L., A. Jerneck, H. Thoren, J. Persson, and D. O’Byrne. 2015. Why resilience is unappealing to social science: theoretical and empirical investigations of the scientific use of resilience. Science Advances 1(4): e1400217. https://doi.org/10.1126/ sciadv. 1400217

Orchiston, C., C. Manuel, M. Coomer, J. Becker, and D. Johnston. 2013. The 2009 New Zealand West Coast ShakeOut: improving earthquake preparedness in a region of high seismic risk. Australasian Journal of Disaster and Trauma Studies 2013(2):5661.

Organisation for Economic Co-operation and Development (OECD). 2017. Socio-economic impacts of disasters in OECD countries. Pages 206-207 in OECD. Government at a Glance 2017, OECD Publishing, Paris, France.

Pahl-Wostl, C. 2006. The importance of social learning in restoring the multifunctionality of rivers and floodplains. Ecology and Society 11(1): 10. https://doi.org/10.5751/ES-01542-110110

Pahl-Wostl, C. 2009. A conceptual framework for analysing adaptive capacity and multi-level learning processes in resource governance regimes. Global Environmental Change 19(3):354-365. https://doi.org/10.1016/j.gloenvcha.2009.06.001

Paton, D., M. Millar, and D. Johnston. 2001. Community resilience to volcanic hazard consequences. Natural Hazards 24 (2):157-169.

Plummer, R., J. Baird, K. Krievins, and S. J. Mitchell. 2016. Improving river health: insights into initiating collaboration in a transboundary river basin. International Journal of River Basin Management 14(1):119-132. https://doi.org/10.1080/15715124.2$\underline{015.1080717}$

Rennie, H. G. 2018. The seduction of fast track recovery legislation: the Mangamaunu surf break saga. Planning Quarterly 211(December):21-27.

Reynolds, R. 2015. Desire for the gap: building community after disaster in Christchurch. Axon 8(1). [online\} URL: http://www. axonjournal.com.au/issue-8-1/desire-gap

RNC Rural. 2015. Rural team collaboration guidelines. [online] URL: https://resiliencechallenge.nz/rural-team-collaboration-guidelines/

RNC Rural. 2018. The resilient rural backbone. [online] URL: https://resiliencechallenge.nz/rural/

Rouse, H. L., R. G. Bell, C. J. Lundquist, P. E. Blackett, D. M. Hicks, and D.-N. King. 2016. Coastal adaptation to climate change in Aotearoa-New Zealand. New Zealand Journal of Marine and Freshwater Research 51(2):183-222. https://doi. org/10.1080/00288330.2016.1185736 
Salinger, M. J., J. Renwick, E. Behrens, A. B. Mullan, H. J. Diamond, P. Sirguey, R. O. Smith, M. C. T. Trought, L. Alexander, N. J. Cullen, B. B. Fitzharris, C. D. Hepburn, A. K. Parker, and P. J. Sutton. 2019. The unprecedented coupled ocean-atmosphere summer heatwave in the New Zealand region 2017/18: drivers, mechanisms and impacts. Environmental Research Letters 14(4): 044023. https://doi.org/https://doi.org/10.1088/1748-9326/ab012a

Schultz, L., C. Folke, and P. Olsson. 2007. Enhancing ecosystem management through social-ecological inventories: lessons from Kristianstads Vattenrike, Sweden. Environmental Conservation 34 (02):140-152. https://doi.org/10.1017/S0376892907003876

Schultz, L., R. Plummer, and S. Purdy. 2011. Applying a socialecological inventory: a workbook for finding the key actors and engaging them. Stockholm Resilience Centre, Stockholm, Sweden.

Smit, B., and O. Pilifosova. 2003. From adaptation to adaptive capacity and vulnerability reduction. Pages 9-28 in J. B. Smith, R. J. T. Klein, and S. Huq, editors. Climate change, adaptive capacity and development. Imperial College Press, London, UK. https://doi.org/10.1142/97818609458160002

Smith, W., C. Davies-Colley, A. Mackay, and G. Bankoff. 2011. Social impact of the 2004 Manawatu floods and the "hollowing out" of rural New Zealand. Disasters 35(3):540-553. https://doi. org/https://doi.org/10.1111/j.1467-7717.2011.01228.x

Spector, S., N. A. Cradock-Henry, S. Beaven, and C. Orchiston. 2018. Characterising rural resilience in Aotearoa-New Zealand: a systematic review. Regional Environmental Change https://doi. org/10.1007/s10113-018-1418-3

Statistics NZ. 2014. Quick stats about Kaikoura District - 2013 Census. Stats NZ, Wellington, New Zealand.

Statistics NZ. 2018. Gross domestic product: June 2018 quarter. [online] URL: https://www.stats.govt.nz/information-releases/ gross-domestic- product-june-2018-quarter

Stevenson, J. R., J. Becker, N. Cradock-Henry, S. Johal, D. Johnston, and E. Seville. 2017. Economic and social reconnaissance: Kaikoura earthquake 2016. Bulletin of the New Zealand Society for Earthquake Engineering 50:343-351.

Stroombergen, A., A. Tait, K. Patterson, and J. Renwick. 2006. The relationship between New Zealand's climate, energy, and the economy to 2025. Kôtuitui: New Zealand Journal of Social Sciences 1(2):139-160. https://doi.org/https://doi. org/10.1080/1177083x.2006.9522416

Tanner, T., D. Lewis, D. Wrathall, R. Bronen, N. Cradock-Henry, S. Huq, C. Lawless, R. Nawrotzki, V. Prasad, M. A. Rahman, R. Alaniz, K. King, K. McNamara, M. Nadiruzzaman, S. HenlyShepard, and F. Thomalla. 2015. Livelihood resilience in the face of climate change. Nature Climate Change 5(1):23-26. https://doi. org/10.1038/nclimate2431

Tau, T. M., A. Goodall, D. Palmer, and R. Tau. 1992. Te Whakatau Kaupapa: Ngâi Tahu resource management strategy for the Canterbury region. Aoraki Press, Wellington, New Zealand.

Thompson, M. A., S. Owen, J. M. Lindsay, G. S. Leonard, and S. J. Cronin. 2017. Scientist and stakeholder perspectives of transdisciplinary research: early attitudes, expectations, and tensions. Environmental Science and Policy 74:30-39. https://doi. org/10.1016/j.envsci.2017.04.006

Tipler, K. S., R. A. Tarrant, D. M. Johnston, and K. F. Tuffin. 2016. New Zealand ShakeOut exercise: lessons learned by schools. Disaster Prevention and Management: An International Journal 25(4):550-563. https://doi.org/10.1108/DPM-01-2016-0018

Turner, B. L. 2010. Vulnerability and resilience: coalescing or paralleling approaches for sustainability science? Global Environmental Change 20(4):570-576. https://doi.org/https://doi. org/10.1016/j.gloenvcha.2010.07.003

Vallance, S. 2015. Disaster recovery as participation: lessons from the Shaky Isles. Natural Hazards 75(2):1287-1301. https://doi. org/10.1007/s11069-014-1361-7

Vallance, S., and S. Carlton. 2015. First to respond, last to leave: communities' roles and resilience across the "4Rs." International Journal of Disaster Risk Reduction 14:27-36. https://doi. org/10.1016/j.ijdrr.2014.10.010

van Aalst, M. K., T. Cannon, and I. Burton. 2008. Community level adaptation to climate change: the potential role of participatory community risk assessment. Global Environmental Change 18(1):165-179. https://doi.org/10.1016/j.gloenvcha.2007.06.002

Walker, B. H., N. Abel, J. M. Anderies, P. Ryan, and others. 2009. Resilience, adaptability, and transformability in the GoulburnBroken Catchment, Australia. Ecology and Society 14(1): 12. https://doi.org/10.5751/ES-02824-140112

Walker, B., L. Gunderson, A. Kinzig, C. Folke, S. Carpenter, and L. Schultz. 2006. A handful of heuristics and some propositions for understanding resilience in social-ecological systems. Ecology and Society 11(1): 13. https://doi.org/10.5751/ES-01530-110113

Walker, B., C. S. Holling, S. Carpenter, and A. Kinzig. 2004. Resilience, adaptability and transformability in social-ecological systems. Ecology and Society 9(2): 5. https://doi.org/10.5751/ ES-00650-090205

Walker, B. H., and D. Salt. 2012. Resilience practice: building capacity to absorb disturbance and maintain function. Island Press, Washington, D.C., USA.

Wang, C., and J. M. Blackmore. 2009. Resilience concepts for water resource systems. Journal of Water Resources Planning and Management 135(6):528-536. https://doi.org/10.1061/(ASCE) 0733-9496(2009)135:6(528)

Whitman, Z. R., T. M. Wilson, E. Seville, J. Vargo, J. R. Stevenson, H. Kachali, and J. Cole. 2013. Rural organizational impacts, mitigation strategies, and resilience to the 2010 Darfield earthquake, New Zealand. Natural Hazards 69(3):1849-1875. https://doi.org/https://doi.org/10.1007/s11069-013-0782-Z

Wilson, T. M., C. Stewart, J. B. Wardman, G. Wilson, D. M. Johnston, D. Hill, S. J. Hampton, M. Villemure, S. McBride, G. Leonard, M. Daly, N. Deligne, and L. Roberts. 2014. Volcanic ashfall preparedness poster series: a collaborative process for reducing the vulnerability of critical infrastructure. Journal of Applied Volcanology 3: 10. https://doi.org/10.1186/s13617-014-0010$\underline{\mathrm{X}}$ 
Yohe, G., and R. S. J. Tol. 2002. Indicators for social and economic coping capacity--moving toward a working definition of adaptive capacity. Global Environmental Change 12:25-40.

Yong, R., M. Browne, and J. Zhao. 2017. Profiling New Zealand's 20 district health boards using the New Zealand index of multiple deprivation (IMD) and the 2013 census. Medical and Health Sciences, University of Auckland, Auckland, NZ. 